Sauti Christian ${ }^{1}$

Manicaland State University of Applied Sciences, Department of Human Resource Management Mutare (Zimbabwe)
331.45:[616.98:578.834(689.1)"2020"

Original scientific paper

Submitted 23/07/2020

Revised 20/08/2020

Accepted 21/08/2020

doi: 10.5937/socpreg54-27652

\title{
BEHAVIOURAL ACTIONS OF SHOP-FLOOR EMPLOYEES TOWARDS OCCUPATIONAL HEALTH AND SAFETY MEASURES DURING THE COVID-19 PANDEMIC RESTRICTIONS. A CASE OF THE AGRICULTURE INDUSTRY IN ZIMBABWE
}

Abstract: COVID-19 pandemic has brought massive suffering to many workers globally. It has disrupted the normalcy and socio-economic fabric in many societies and has redefined the nature of the world of work. Several restrictions and measures to mitigate the spread and implications of Coronavirus have been put in place through government and individual employer efforts. These include the compulsory use of masks, body temperature tests, avoidance of unnecessary movement and maintenance of social/physical distancing among other occupational health and safety practices. Based on the findings from two selected timber sector organisations in Zimbabwe, employees have non-congruent behavioural actions to conform and adhere to the OHS measures for COVID-19. The management believes that shop-floor employees are not scared of the pandemic; they think that the virus is an illusion. Employees resist respecting social/physical distancing due to their cultural beliefs and value; some are even stealing hand sanitisers for other uses rather than the prevention of COVID-19. The study recommends effective training, awareness campaigns and effective communication for culture change and to help workers appreciate that COVID-19 is very deadly and is a reality. Taking disciplinary action for non-compliance of shop-floor employees has created negative perceptions and led to counterproductive behaviours among workers towards efforts to manage and control the spread of COVID-19 in the workplace. Trade unions and worker committees have a role to play in enhancing communication and advancing workers interests for improvement of decent working conditions in the face of Coronavirus. The state and employers should ensure respect for fundamental rights of the precariats who are soldering on in the pandemic context.

Keywords: Agricultural Industry in Zimbabwe, Coronavirus (COVID-19), Co-Evolution, Postmodernism, Pandemic, Precariat, Occupational Health and Safety (OHS)

\footnotetext{
1 sautichristian@gmail.com
} 


\section{Introduction}

Natural disasters threaten the efficiency and reputation of organisations and the social fabric of the societies. Disasters which have detrimental effects to the integrity of companies, workers or the community are the least expected though they always occur. Disasters particularly in Zimbabwe are complex emergencies and planning for them is very difficult. Disasters are relatively wicked problems which require post-normal strategies to address them. Minzberg (1994) emphasized that certain strategies were key to mitigate the implications of disasters but organisations should appreciate that strategies emerge over time as intentions collide with and accommodate changing realities. The experiences of COVID-19 pandemic proffered a serious threat to the world of work; it redefined the nature of employment relations, working conditions and other patterns of the working lives worldwide. COVID-19 is a pandemic affecting many countries globally; it has become a social phenomenon and a dominant feature affecting the world of work in many respects. Coronavirus is the new normal; it is an emergency defined by chaos, complexity and entropy which renders proactive planning invalid particularly in the Zimbabwean context. Investing in disaster preparedness makes a social and business sense (Maunganidze, Ncube and Sibanda, 2013). Through the Ministry of Health and Child Care the Zimbabwean government developed several strategies and measures to mitigate the spread and effects of Coronavirus. Some of the measures introduced for industry include the compulsory use of masks, hand sanitisers and temperature tests for all workers in the workplace. Other employers introduced awareness campaigns, hibernation centres for workers suspected of having the virus, as well as guidelines for hygiene and preventive measures against the spread of COVID-19 in the workplace. Occupational health and safety policies to deal with Coronavirus were developed and the code of conduct is used to foster compliance with COVID-19 regulations. However, all these efforts are meaningless if there is a lack of mutual cooperation from workers towards the fight against COVID-19. This study sought to deconstruct employee attitudes towards the OHS measures for COVID-19 pandemic restrictions in Zimbabwe.

\section{COVID-19 Pandemic}

It is a fact that natural disasters and accidents do happen no matter how prepared one is: more often than not, they happen when we least expect them. Ncube (2014) made reference to the 1972 Hwange Colliery Kamandama Disaster which claimed the lives of 427 mine workers. The same study revealed that an accident or disaster of any magnitude had grave implications on human beings and caused serious damage to the environment and survival of a number of families. The same views refer to the March 2019 Cyclone Idai. The cyclone affected the livelihood of many people in Mozambique and Zimbabwe, particularly in Chimanimani District. Many people were left homeless, families and friends and future workforce perished due to the natural disaster during the night of Friday, 15 March 2019. To date, the effects of Kamandama disaster and Cyclone Idai, to mention but a few, are still compromising the socio-economic fabric of the Zimbabwean economy. Maunganidze, Ncube and Sibanda (2013) investigated the practicality of pro-active planning for disasters in the workplace. They established that no matter how well plans are made, disasters do happen. The impact of such disasters is exacerbated by human behaviours 
and attitudes towards the application of health and safety contingency plans and supporting structures. Some could not believe that COVID-19 is a reality, but they have resistance towards the adherence to the restrictions imposed by the government, WHO, ILO and individual organisations.

Coronavirus disease (COVID-19) is an infectious respiratory disease caused by a new virus called SARS-CoV-2. The disease causes a respiratory illness similar to flu with symptoms such as fever, cough and difficulty in breathing. COVID-19 started in China in December 2019. The World Health Organisation (WHO) declared the outbreak of COVID-19 in January 2020 in Hubei Province of China. Coronavirus disease was declared to be a public health emergency internationally. According to the International Labour Organisation (ILO), Coronavirus spreads through droplets transmission. When someone with COVID-19 coughs or exhales, they release droplets of infected fluids and these droplets fall on nearby objects or surfaces. One could catch the disease by touching contaminated areas or objects and then by touching their faces. COVID-19 spreads in the same way as flu. WHO (2020) stated that on 19 July 2020 there were 14.4 million cases of Coronavirus disease, with 8.03 million recoveries and 603,000 deaths. According to the report of the Ministry of Health and Child Care of 19 July 2020, there are 1,478 confirmed cases, 439 recoveries and 25 deaths in Zimbabwe. These figures show a rapid increase compared to 479 cases, 63 recoveries and 4 death cases in Zimbabwe on 19 June 2020.

\subsection{Lockdown situation in Zimbabwe}

COVID-19 has left many people worldwide without any means for survival. ILO (2020) reveals that Coronavirus disease has left millions of workers without security, income and food, whereas their future is very uncertain. It has led to a drop of $60 \%$ in the income of workers globally and for the most vulnerable groups in the labour market, 3.3 billion work force have suffered massive damage to their capacity to earn a living due to the crisis caused by the pandemic. Thus, Uzhenyu (2020) reinforces that COVID-19 has affected all aspects of life and industrial relations dynamics at large in Zimbabwe. Lockdown measures are one key issue of concern worsening the situation of the precariat workers in Zimbabwe, to be specific.

The government of Zimbabwe introduced several measures to combat the spread and effects of COVID-19. As indicated by Uzhenyu (2020), Zimbabwe embarked on the initial 21-day national lockdown on Monday, 30 March 2020, which was called level 4 lockdown. All businesses were closed except those in the essential services such as security agents, health sector, service stations, food manufacturing sectors, and public transport. During this phase, all gatherings of more than 50 people were prohibited as a means of advancing social distancing, and the use of sanitisers and disinfectants and maintenance of personal hygiene were advocated for. The closure of many organisations means that the majority of workers stayed at home, amid fears regarding health, safety and of job security.

After the lapse of level 4 lockdown, the government declared another 14 days on 3 May 2020 with a few flexibilized restrictions (African Research Bulletin, 2020). A few organisations, such as those in the mining sector, were allowed to operate during this level 3 lockdown period. Then level 2 lockdown phase was announced, which saw the re-opening of many formally registered businesses. Other businesses like kombi transport, entertainment, 
schools, hospitality industry and the informal sector remain closed. During this period, the business operating hours were specified from 8.00 a.m. to 3.00 p.m. except for those in the essential services and approved in terms of Statutory Instrument 99 of 2020 . The government declared mandatory requirements for the prevention of COVID-19 which include but are not limited to body temperature testing, compulsory wearing of masks, provision of disinfectants and hand sanitisers in all workplaces. These were health and safety measures to curb the spread and effects of Coronavirus disease. On 18 May 2020, the state announced an indefinite lockdown aligned to level 2 phase, giving some organisations an opportunity to resume operations but on the condition that they respect and adhere to the COVID-19 restrictions. The hospitality industry was allowed to start operations and business hours were extended up to 4:30 p.m.

COVID-19 has caused massive suffering to workers in Zimbabwe (Uzhenyu, 2020). According to ILO (2020), workers with precarious employment had their contracts terminated; some employees had their salaries cut while others could not even receive any part of their salaries due to low businesses and impossibility to effect payment. Some organisations forced workers to go on vacation leave during the whole lockdown period and those without sufficient leave days were advised to go on unpaid leave (UPL), whereas some employees were encouraged to take 12-day special leave which was then considered as their vacation leave. Other employers opted to go for retrenchment due to the natural disaster and their inability to pay workers during the pandemic. The government implemented Statutory Instrument (SI) 99 of 2020 and Statutory Instrument 81 of 2020 (Specification of Minimum Wages effective as of 1 April 2020). The SI stated that every employer should pay the minimum wage of RTGS $\$ 2,549.74$ (Zimbabwean Dollars) which is equivalent to $\$ 43.00$ (US Dollars), with the exception of the agricultural sector.

Notice 005/03/2020 from the National Employment Council for the Agricultural Industry in Zimbabwe classified the agricultural industry as an essential service during the lockdown period. Employers in this industry were urged to provide employees with personal protective equipment and clothing to prevent the risk of exposure to COVID-19 in the workplace. However, in as much as the government and companies have been putting efforts to contain COVID-19 and its impacts on the economy and workplaces, there are mixed reactions among employees towards the Coronavirus disease restrictions. This articles sought to critically investigate the behaviours of workers towards the COVID-19 pandemic restrictions using the agricultural industry in Zimbabwe.

The study answers the following major research question:

What are the behavioural actions expressed by employees towards the OHS measures for the COVID-19 pandemic?

Specific objectives are:

a. To establish the impact of COVID-19 on employment relations and working conditions.

b. To describe behavioural actions of employees towards Coronavirus disease restrictions.

c. To find out strategies that help manage non-congruent behaviours of employees. 


\section{Theoretical Framework}

\subsection{Co-Evolutionary Theory and Postmodernism in relation to COVID-19}

Organisational success and performance is premised on concerted efforts, attitudes and behaviours of human capital. A strong integration of the company's internal strategy and its operating environment, a tight fit among structures, processes, capabilities and management, lead to high performance (Maunganidze et al, 2013). One of the major challenges affecting companies in the agricultural industry particularly in Zimbabwe is the ever-changing business context, complexity and uncertainty especially in the event of natural disasters and emergencies. Postmodernism has been adopted to guide this study, the main argument being that the practices, plans and restrictions developed to manage COVID-19 are actually a product of complicated discursive practices of preparedness, laws of discourses and ideological effects (Fischer, 2003). According to Maunganidze et al (2013), investing in disaster preparedness is reasonable and justified in a social and business sense. The postmodernist position implies that there are multiple realities constructed by individuals; if there is no fixed reality then humans cannot know the truth. Multiple realities call for different methods of addressing the COVID-19 pandemic. Postmodernism is closely aligned with the collapse of grant narratives, systems of legitimacy, determinacy and consensus in the face of Coronavirus disease. In explaining the rise and impact of COVID-19, the new normal, postmodernist abandon the use of universal methods and macro-explanations in favour of emergent strategies to curb the problematic aspects of Zimbabwean experiences. The co-evolution theory reinforces that organisations evolve in relation to their environment and changes in any socio-economic landscape have a positive or negative effect on business viability and survival (Lewin and Vilberda, 1999). Company A and B are subject to Coronavirus disease, which is a threat for business efficiency. The success is based on their ability to cope, co-evolve in the face of COVID-19, address challenges intensified by the pandemic and rebuild a positive culture among employees.

\section{Methodology}

The study adopts a qualitative research design and it is based on postmodernism. The study was carried out using the case study of two timber companies, Company A and Company B, which operate in the agricultural sector in Zimbabwe. The content analysis of company documents such as health and safety reports, policies and procedures, and media reports and thematic analyses were used. Both primary and secondary data were used. A total of 40 participants was used to gather data for this study; 5 of them were managerial participants, 4 from HR, 10 were the Worker Committee representatives, 2 were union representatives and the remaining 19 were shop-floor workers. Focus group discussions were used to collect data from shop-floor workers and worker committee representatives while face to face interviews were performed to obtain data from management, HR and trade union members. 


\section{Findings}

\subsection{Impact of COVID-19 on industrial relations and working conditions}

The study established several impacts of Coronavirus disease on employment relations and working conditions in the agricultural industry in Zimbabwe. Management participants pointed out that the closure of companies and borders following the declaration by the state affected the cash flows for the export market. This reduced revenue generation and organisational ability to pay wages for their workers. One management representative from Company A went on to state that:

"One notable impact of COVID-19 in the industry is that, as businesses we rely on the export market in Botswana, Mozambique and South Africa. Lockdown has led to the closure of main border posts hence no transportation of our products to the external market. This means that we are stuck, we are left with no options for revenue generation, no access to foreign currency and also we have no means to get spare parts from outside. We are currently operating below $30 \%$ due to COVID-19 and this is not healthy and lacks business sense in my view."

In the same way, the management participants from Company B reinforced that the travelling and export restrictions due to the lockdown measures had implications on the financial base of their company. The company is incapable of paying salaries or providing any salary increments to the workers to cushion the unprecedented inflation and the growing cost of living. The trade unions members also revealed that the Coronavirus pandemic had negative impacts on the remuneration of workers as many employers failed to pay wages because of very low sales.

The shop-floor workers were of the opinion that the agricultural companies were classified as essential services, so the employers were supposed to pay them sufficient salaries religiously during the lockdown period. One of the representatives from the Worker Committee (WC) said:

"We have been classified as an essential service so we have been working during the lockdown period except for a few individuals who went on vacation leave. During this period, our employer failed to increase our salaries or give us a risk allowance because COVID-19 is a deadly disease. We thought we were going to receive an allowance for working under unsafe conditions as prescribed in the Labour Act, or that the employer would pay us overtime at the holiday rate as a token of appreciation for working under a safety and health threat."

The managements of both companies indicated that the companies had no capacity to adjust salaries and allowances because the sales were low; there was mass production, of course, but all the goods were stocked in the warehouses. They also said that business was an art, a process of producing and selling, so when you produced without sales then you were doomed to failure.

Nineteen participants from the group of shop-floor workers reiterated that lockdown proffered travelling restrictions and they faced travelling challenges to go from town and buy basic commodities. The same participants went on to state that the wages they received were poor to the extent that they failed even to cater for bus fares, while they hoped to 
receive food hampers from the employers during the lockdown period. On the same note, the management said that they had no capacity to secure food hampers because of food shortages and inflation in the local shops.

The Worker Committee members stated that employees from both companies were forced to go on vacation leave and unpaid leave in case they did not have enough vacation leave days. The management participants opined that the lockdown was the opportunity to send employees on vacation leave and reduce the leave liability. However, a trade union representative stated:

"We have seen these employers forcing employees to go on vacation leave and some were placed on short-time during the lockdown period. Salaries were cut and this has a serious effect on the lives not only of workers but their families and community. Imagine staying at home without any source of income; it is not reasonable for a good employer to place employees on unpaid leave. Lockdown is just a phase, employment is the source of living for workers, so 1 thought as part of their retention strategy companies should have been paying salaries and not short-time. This is a natural disaster; we are there to help each other. At law, it is not specified, but it is just based on good practice to at least give workers special leave, pay them whilst at home to support their socio-economic needs."

In relation to employment contracts, HR representatives and WC members reiterated that COVID-19 disease had worsened the situation of job insecurity for the precariats. These participants submitted that the majority of workers in the companies were on Fixed Term Contracts and Casual Contracts. Due to Coronavirus disease and lockdown restrictions, their employment contracts were terminated on notice. A union official argued that COVID-19 worsened the position of the lumpenproletariat, or precarious workers; it was a catalyst for their suffering and continued income and job insecurities. The management participants argued that, due to lockdown, the organisations had been left without any option than to terminate contracts of temporary workers. This was righteous to save companies from high labour costs against low production.

The majority of the shop-floor workers, trade unions, HR and worker committee members evidenced that COVID-19 had brought a myriad of occupational health and safety challenges and impacts in the industry. The participants argued that, before the outbreak of COVID-19, the companies had failed to provide enough personal protective equipment so the employees were working without safety clothing, goggles, gloves and shoes. This was the norm mainly for the precarious employees and the participants revealed that they were very vulnerable to the risk of COVID-19. The outbreak of COVID-19 and its safety requirements brought another striking challenge for the companies. This is what one management participant had to say:

"Due to lockdown, we are not able to secure PPE outside, and we cannot afford to purchase it in Zimbabwe for more than 700 employees, it is very expensive. In relation to the OHS requirements for Coronavirus disease, we are still struggling but we have managed to provide masks and temperature testing machines and hand sanitisers in the workplaces."

The management participants also highlighted that the fears associated with Coronavirus affected employee performance. The trauma and fears of COVID-19 create high insecurity levels among employees, which destroys motivation, commitment and engagement. Employees are likely to exhibit counterproductive behaviours when their safety and 
security are threatened and. according to the statements of the management, COVID-19 is the element of low labour productivity in the agricultural industry.

Social and physical distancing was one of the COVID-19 restrictions pointed out by virtually all participants (Table 1). Through focus group discussions, WC and shop-floor workers agreed that social and physical distancing was a measure meant to avoid the spread of Coronavirus disease in the workplace. The same participants highlighted that physical and social distancing was not easy due to cultural values and norms and the workplace setup of their roles as well. One of the shop-floor participants went on to say the following:

"The government encouraged everyone to maintain social distance, but it is not practical to maintain social and physical distance from my work colleague and my family. In the plant, we exchange products from one centre to another to make the final goods and this is a chain. Sometimes we even work without safety gloves so the risk of the spread of the virus is high. So, as workers, it is our wish to refuse to work under these conditions because this is a serious threat to our health but look, we are surviving under the mercy of these employers. This is the reason why we usually express counterproductive behaviours, we are afraid to die."

Interestingly, another WC member said:

"We cannot be forced to maintain social and physical distance, we are used to mushandirapamwe (a Zimbabwean philosophy that means working together as one). I think it is a lie to say COVID-19 exist in Zimbabwe; just show us one local person who is affected and has died due to that virus."

The management participants indicated that the maintenance of social and physical distance was very difficult considering the nature of jobs. One of the management representatives stated:

"Sometimes, these workers refuse to maintain social and physical distance because it is not normal to them. They do not believe that Coronavirus is a reality. They could hug, exchange food and all sorts of contacts in the workplace without any fear of the pandemic."

Some shop-floor workers were of the view that face masks were mandatory but their essence for the prevention of Coronavirus disease was not realistic. The management indicated that the shop-floor workers did not put on masks saying that the masks caused difficulties in breathing. Some of the workers are now using masks to protect themselves from dust and not to prevent the spread of COVID-19. The worker committee and HR participants provided a different opinion from the management, arguing that workers were not really scared of the Coronavirus pandemic. The HR participant stated that workers were not productive as they used to be before the pandemic because they were so afraid and working in the panic mode.

One of the restrictions in relation to COVID-19 is to stay at home and avoid unnecessary travelling. The study revealed that workers in the agricultural industry were still going to work during the pandemic era and due to their high socio-economic demands, they could not afford to stay at home. Through focus group discussions, the participants argued that the restrictions, especially those on travelling, were meant to stop demonstrations, they were not purely meant to mitigate the implications of Coronavirus but to safeguard political interests. A participant from the WC stated that: 
"We are told to stay at home but the NEC said we are an essential service, so we are still going to work, we need food and other basic commodities. It is not feasible to stay at home lest we will perish from poverty. During weekends and on our off days, we travel to Mozambique to buy cheap basic commodities: we cannot sustain a living with our salaries so we are compelled by the whip of hunger to look for food in Mozambique. If the government provided us with basic goods, we would greatly appreciate it and be able to stay at home."

On temperature screening, the management participants submitted that the companies had purchased the equipment for testing at all entrance points. However, employees refuse to be tested because the test kits always provide invalid results due to the weather patterns in the areas. One of the shop-floor workers said:

"I do not trust the tests because the equipment is malfunctioning. I think our temperatures this side are very low, this area is very cold and that testing equipment sometimes records 0 degrees Celsius. There is no need to have these tests."

Some of the participants from HR and WC, as well as the shop-floor workers indicated that the use of hand sanitisers was not a noble idea in the agricultural industry. They argued that in the morning it was very cold and since it was the winter season, workers were refusing to wash or sanitise their hands. This is one of the behaviours causing the high risk of COVID-19 in the agricultural industry in Zimbabwe. The management representatives also stated that shop-floor workers stole hand sanitisers and disinfectants for other uses other than the prevention of Coronavirus.

All shop-floor workers, union officials and management participants reiterated that everyone was restricted from touching the face as a means to prevent the risk of Coronavirus disease. One of the management participants said that workers performing dirty jobs sweated and did not have any option than to touch their faces to clear the sweat. To avoid touching the face (mouth, eyes and nose) is a myth in the industry.

\subsection{Managing employee behaviours during COVID-19 pandemic}

An interesting point was raised by the management participants on the management of employee behaviours during the Coronavirus pandemic. The participants reiterated that there was a need to adopt awareness campaigns and training of employees to enable them to understand issues around COVID-19. One of the participants stated:

"Some of our employees do not understand that COVID-19 is a reality, they want to believe after witnessing a case in the workplace. Though there is a death toll due to Coronavirus, people just do not believe, they are doubting Thomases. In order for them to understand, there is a need for training and for embarking on some awareness campaigns. This will help to transform a culture of resistance among our staff so that they appreciate that Coronavirus is the new normal, and preventive measures should be respected."

The trade union officials and WC members submitted that the companies needed to provide employees with food hampers and basic commodities as a way to avoid their unnecessary movement and travelling to Mozambique. Furthermore, they said that the state should also provide free food to the population to cushion the food crisis currently 
forcing the communities and employees to violate the occupational health and safety measures meant to mitigate the spread and effects of COVID-19 pandemic.

Four management participants were of the opinion that employees should be punished for non-compliance with the COVID-19 restrictions. As indicated in Company B's employment code of conduct, section 3.6, violation of safety and health procedures and policies renders a disciplinary action which warrants a final or a more severe award. One participant from the management went on to say:

"Employees who violate OHS measures meant to curb COVID-19 should be punished. Even the state through the Police and Military is suing the public who are caught without masks, so this is the way to go in the workplace. Even those who steal hand sanitisers should face disciplinary action, such non-congruent, deviant behaviours are not acceptable."

The HR participants pointed out that trade unions and WC had a key role to play in fostering positive behaviours towards adherence to OHS measures for COVID-19 in the agricultural industry. The participants agreed that it was the role of worker representative forums to address people's OHS concerns, air them to management and build mutual cooperation within the industry in the fight against Coronavirus. One of the participants from HR said:

"Unions like the General Agriculture and Plantation Workers Union of Zimbabwe (GAPWUZ) should be active in educating workers to obey the restrictions levels against COVID-19 disease. Unfortunately we never saw them even a single day addressing workers on the ways to combat Coronavirus in the workplace. Our employees trust unions so we are kindly asking them to come and intervene towards the fight against the COVID-19 pandemic. Such mutual cooperation is the best way for both business and social integrity."

\section{Discussion}

\subsection{Impact of COVID-19 on industrial relations and working conditions}

The study has established that Coronavirus disease has several impacts on employment relations and working conditions in the agricultural industry in Zimbabwe. Coronavirus has affected business viability due to the closure of the borders and export market. This has weakened organisational ability to remunerate and adjust wages for workers during the lockdown period. This is in line with Ncube (2020) who reiterated that COVID-19 had redefined the nature of employment relations in Zimbabwe. Employers have been unable to exploit the foreign market and generate high revenue. This has ushered challenges for workers in different fashions. Some employers could not afford to pay wages and salaries while some would send employees on forced vacation leave (Uzhenyu, 2020). This is a clear testimony that COVID-19 has transformed the face of industrial relations and working conditions in Zimbabwe.

The research found out that Coronavirus disease had exacerbated the termination of contracts for temporary workers. It has accompanied high levels of job insecurity for workers with precarious employment in Zimbabwe's agricultural industry. The same views are supported by Uzhenyu (2020) who states that due to COVID-19, many employers terminated contracts for fixed term and casual workers. This means that securing a job during 
the Coronavirus era is a blessing; workers with precarious employment endure employment insecurities, which affects their families and lives in general. Permanent employees are still under fear of being retrenched; they are working at the mercy of employers as they fear to be downsized on the basis of a natural cause.

Findings reveal that COVID-19 affects industrial relations and employee morale in the workplace. Employees are working without personal protective clothing hence they are vulnerable to the risk of Coronavirus. This situation could affect the psychological contract and motivate workers into counterproductive behaviours, and they react in a bid to restore their personal safety. This is in sync with Bhebhe (2020) and Lang (2020) who argue that COVID-19 is a catalyst for worker disengagement and criminogenic actions, which leads to counterproductive behaviours such as sabotage and poor service delivery. Coronavirus has negative impacts on the relationship between employers and employees. Its obstacles would imply that managements are not supportive and concerned of its human resources as they fail to secure enough safety clothing to protect workers against COVID-19.

\subsection{Deconstructing employee behaviours towards restrictions for COVID-19 disease}

Findings reveal various behavioural actions exhibited by employees towards OHS measures to mitigate the spread of COVID-19 in the workplace. The majority of participants submitted that socio-cultural values are so strong and social/physical distancing is the means to break the social ties in workplaces and societies. ILO (2020); Ozili (2020) reinforced that the restrictions meant to contain Coronavirus were violated in most African societies and workplaces because of the cultural and social beliefs. Employees in the agricultural industry have resistance towards social and physical distancing because they do not appreciate that COVID-19 is a reality.

The fear of job insecurity is one major issue of concern causing workers to soldier on without protective clothing to avoid the risk of COVID-19. As revealed in this study, workers are working at the employers' mercy. This indicates that shop-floor workers are subject to precarious working conditions, they are punished and dismissed willy-nilly hence they suffer high levels of job insecurity. This is in tandem with the employment strain model by Lewchuk, de Wolff and King (2003) which states that unstable working conditions and uncertainty creates a sense of fear, anxiety, frustration and survivor syndrome which is counterproductive in nature. This means that when employers resort to unnecessary terminations, unfair dismissals or retrenchments in this Coronavirus pandemic, the remaining employees will suffer a great deal of emotions, stress and insecurity. The stayers will therefore resort to forms of non-congruent actions such as pilferage, sabotage, and fiddling just to try to restore their workplace freedom from the exploitative capitalist working context.

The study reveals that workers are therefore reporting for duty daily, but working without sufficient PPE in order to secure employment and receive their poor wages. Their job design does not allow for social distancing hence there is resistance to the adherence to OHS measures for Coronavirus. This is congruent with ILO (2020); WHO (2020); African Research Bulletin (2020); Keune and Pedaci (2019) who argue that most of precarious workers have limited workplace rights, so they are the most vulnerable to being affected by COVID-19. These workers are subject to exploitations and various forms of indecent 
working conditions. Employees who work under unsafe conditions can adopt survival strategies such as stealing chemicals or tools meant to safeguard against COVID-19. This is a way to restore their freedom and control the workplace situation in the face of Coronavirus.

The study results indicate that employees are using masks to protect from dust and not to prevent the spread of COVID-19 and they believe that COVID-19 restrictions such as travel restrictions are meant to sustain political interests by avoiding demonstrations in Zimbabwe. This view is related to the planned demonstrations of 31 July 2020 which were organized against claims of human rights abuse and unprecedented crisis in Zimbabwe. Chirimambowa (2020) supports the view of the workers in the agricultural industry by arguing that in Zimbabwe, the pandemic ushered a perfect opportunity to checkmate the ever nagging opposition and civil movement and the COVID-19 restrictions are meant to achieve unimpeded imperial authoritarianism. The government of Zimbabwe stopped the demonstrations to avoid the rapid spread of the Coronavirus pandemic but to the workers in the agricultural sector, it was deemed as a means to prevent demonstration and workers' exercise of their right to social justice and democracy. The Ministry of Health and Child Care submits that employees have a tendency to resist the use of masks, but masks are very important to prevent the spread of COVID-19. Masks avoid droplets transmission and they are not meant to prevent occupational dust in the workplaces. It is necessary to educate employees to appreciate that Coronavirus can be spread through droplets transmission hence the use of masks is a noble way of minimising the risk (United Nations, 2020).

The study shows a contradiction of two opinions proposed by the management and employees respectively in relation to the understanding of COVID-19 and employee behaviours. The management believes that shop-floor workers are not scared of the pandemic because they could even share food and hug which is against the OHS measures to prevent COVID-19 like the maintenance of social and physical distancing. On the other hand, workers and HR attribute low labour productivity to the workers' fears of the deadly pandemic. Maunganidze (2014); Ncube (2020) argued that management always served their vested interests without proper considerations of the OHS needs of the proletariat. Shopfloor workers are socially cut-off, they are the living poor so sharing food is a norm, and it is difficult to believe the motives of non-compliance to OHS measures without addressing their socio-economic needs. When employers show no commitment to support workers and provide safety and health clothing and required equipment to guard against COVID-19, workers will obviously refuse to comply but will exhibit deviant behaviours.

\subsection{Managing employee behaviours during the COVID-19 pandemic}

Findings revealed that organisations should adopt awareness campaigns and training of employees to understand issues around COVID-19. As a preventive measure, employees should be educated so that they fully understand the effects and ways of managing Coronavirus. Uzhenyu (2020); ILO (2020); WHO (2020) share the same argument. They argue that organisations need to train their staff on hygiene and other preventive measure to avoid the risk of COVID-19. Training and awareness campaigns would build a new culture among workers to appreciate that Coronavirus is the new normal (Wilder-Smith and Freedman, 2020). This will create mutuality and a fit between employees and their firm together with the environment. Organisations need to train employees so that they are able 
to gain their commitment and profound motivation amid the Coronavirus pandemic. This would enhance the ability of organisations to co-evolve and cope with the pandemic and adopt survival strategies for success.

Trade unions and worker committees need to play a significant role in educating and communicating with workers on the nature and impacts of COVID-19 in the workplaces. Ncube (2020) argues that trade unions remain relevant despite the changes and disasters taking place globally. Effective communication can be achieved through trade unions and worker committees in the workplace because they are viewed as important bodies by employees who seek to air their concerns and grievances. The same unions should negotiate with management to provide PPE and save lives.

The study has found out that management believes that disciplinary action should be taken against employees who breach OHS measures established for COVID-19. The Employment Codes of Conduct are applied to discipline employees who violate COVID-19 preventive measures and this is a clear testimony of the precarious position of workers in the agricultural industry. This is in line with Maunganidze (2014) who questions the operatic nature of employment codes. The same author argues that in their operation, Codes of Conduct are part of a stratagem that serves to legitimise power, control and exploit shopfloor workers by management. The application of the employment codes for breaches relating to COVID-19 regulations is not necessary especially when employers are even failing to provide sufficient protective equipment to avoid the vulnerability of workers to Coronavirus disease. Employees are very insecure because of devastating and threatening working environment; they are working without sufficient protective clothing while simultaneously receiving slave wages below the poverty datum line. Punitive disciplinary hearings and dismissals for non-compliance with OHS measures meant for the pandemic are not rational from the perspective of Foucauldian concepts because they are reduced to either penal or rules acts, thus not addressing the humanitarian concerns of the workers amid COVID-19.

\section{Conclusions and Recommendations}

It has been observed that COVID-19 is a reality; it is the new normal. Several restrictions or measures meant to mitigate the spread of Coronavirus are of significant importance. The article has found out that Coronavirus has a grave impact on the working conditions and employment relations. Workers are vulnerable to unsafe working environment, they are receiving poor wages, and some are even disciplined for non-compliance with safety regulations and as for the precariats and their contracts. They are surviving at the mercy of employers as they experience high job insecurity levels. These issues have a serious impact on employee engagement, morale and motivation; they affect the operation of the psychological contract as they create trauma and fears among employees. The study reveals that restrictions such as compulsory body temperature tests, use of face masks and social distancing are disputed by employees as a means of distracting social ties and cultures, and also safeguarding political interests of others. This has led to massive resistance towards the adherence to OHS measures meant for COVID-19 in the agricultural industry. Negative perceptions and the lack of appreciation for the relevance of restrictions by employees mean that there is a need for strategic intervention for the application and operation of measures to manage COVID-19 in the Zimbabwean economy. 
The research argues that there is a need for training, effective communication through worker committees and trade unions, awareness campaigns and management commitment to furnish workers with sufficient personal protective equipment and accommodate the weather patterns so as to gain support from staff. The fight against Coronavirus should be mutual, behavioural actions should be supportive and integrated to sustain both individual and organisational needs. COVID-19 is a social phenomenon; it is a "cankerworm" which disturbs the socio-economic efficiency worldwide. As submitted by Lone and Ahmad (2020), employees should be encouraged to respect OHS measures for COVID-19 and believe that this is the new reality defining the world of work in the $21^{\text {st }}$ century. The use of employment codes is not recommended since they worsen the precarious position of workers and present the exploitative nature of management without addressing the real substance. The use of codes can create resistance and conflicts, hence the need to apply other non-punitive means like training and effective communication to address the threat of Coronavirus disease.

There is a need to protect workers from precarious working conditions which are additionally exacerbated by the COVID-19 pandemic worldwide as well as in Zimbabwe in this specific case. COVID-19 has become the new normal; it has redefined the nature of the world of work. Some workers were retrenched; those with temporary employment had their contracts terminated on notice, while others whose contracts had expired were unfairly dismissed. Employers need to respect the fundamental rights of workers, especially those enshrined in the UN Universal Declaration of Human Rights, and the ILO. In Zimbabwe, employers should protect the interests and rights of workers prescribed in the Labour Act (Chapter 28:01), the Constitution of 2013 and the Model Employment Code (Statutory Employment 15 of 2006). Adherence to the labour law provisions will enhance decent work and promote harmonious industrial relations, equally leading to superior performance and competitive edge.

The healthcare and OHS capacity of the country and organisations plays a critical role in the management and control of COVID-19. Lone and Ahmad (2020) argue that the United Kingdom, the United States of America and China have advanced healthcare systems but are struggling with containing Coronavirus disease. For the developing African countries like Zimbabwe which have weaker healthcare sectors, there is a need to learn from the current crisis about preparedness for the future natural disasters. Although several strategic measures like lockdowns, travel bans, ban on large gatherings and the compulsory wearing of masks were introduced to control the spread of COVID-19 in many African countries, governments have yet to improve their healthcare facilities and corporates also need to focus on human resources in the workplaces so as to show that they really appreciate the essence of such COVID-19 measures.

This study is based on behavioural actions of employees towards OHS measures for COVID-19 in the agricultural industry in Zimbabwe. Further research using multiple case studies from different industries is recommended to make a comparative analysis of behaviours, attitudes and perceptions of employees towards the restrictions related to COVID-19. 
Саути Кристијан ${ }^{1}$

Маникаланд државни универзитет примењених наука,

Департман за управљање људским ресурсима

Мутаре (Зимбабве)

\title{
ОБРАСЦИ ПОНАШАҢА ЗАПОСЛЕНИХ У ОДНОСУ НА МЕРЕ ЗАШТИТЕ НА РАДУ У КОНТЕКСТУ РЕСТРИКЦИЈА ТОКОМ ПАНДЕМИЈЕ COVID-19. ПРИМЕР ПОЉОПРИВРЕДНЕ ИНДУСТРИЈЕ У ЗИМБАБВЕУ
}

\author{
(Превоg In Extenso)
}

Сажетак: Пандемија COVID-19 проузроковала је огромне невоље великом броју радника на глобалном плану. Пореметила је нормалан живот и друштвено-економски миље у многобројним друштвима, те дала нову дефиницију природе света рада. Извесна ограничења и мере за спречавање ширења и последица коронавируса уведени су захваљујући напорима владе и појединачних послодаваца. Оне, поред осталих мера безбедности и здравља на раду, обухватају обавезно ношење маске, мерење телесне температуре, избегавање непотребног кретања и одржавање социјалне/физичке дистанце. На основу налаза две одабране организације из дрвне индустрије у Зимбабвеу, запослени се понашају неусклађено када је реч о поштовању и придржавању мера безбедности и здравља на раду уведених због вируса COVID-19. Руководство верује да се запослени не плаше пандемије и мисле да је вирус варка. Запослени пружају отпор социјалној/физичкој дистанци због културолошких уверења и вредности; неки чак краду дезинфекционо средство за руке и користе га у друге сврхе уместо за спречавање вируса COVID-19. Ова студија препоручује ефикасну обуку, кампање за подизање свести и делотворну комуникацију у циљу промене у култури и помоћи радницима у поимању чињенице да је COVID-19 веома опасан по живот и да је то наша стварност. Покретање дисциплинских мера против запослених због непоштовања мера створило је негативне перцепције и довело до контрапродуктивног понашања радника према напорима да се управља и контролише ширење вируса COVID-19 на радном месту. Синдикати и раднички савети имају улогу у побољшању комуникације и заговарању радничких интереса у циљу постизања пристојнијих услова рада у контексту коронавируса. Држава и послодавци треба да осигурају поштовање фундаменталних права радника који и даље раде током пандемије.

Кључне речи: пољопривредна индустрија у Зимбабвеу, коронавирус (COVID-19), коеволуција, постмодернизам, пандемија, прекаријат, безбедност и здравље на раду (БЗР)

1 sautichristian@gmail.com 


\section{1. Увод}

Природне катастрофе угрожавају ефикасност и репутацију организација и социјални миље друштва. Најмање се очекују катастрофе које имају штетне утицаје на интегритет компанија, радника или заједнице, али се ипак дешавају. Катастрофе у Зимбабвеу односе се на нарочито сложене ванредне ситуације, па је планирање у вези са њима веома тешко. Катастрофе су прилично крупан проблем који изискује доношење стратегија за нормализацију. Minzberg (1994) истиче да су одређене стратегије биле кључне у ублажавању последица катастрофа, али да би организације требало да поштују чињеницу да с временом настају стратегије, а да се намере сукобљавају и прилагођавају стварности која се мења. Искуства из пандемије COVID-19 указују на озбиљну претњу свету рада; пандемија је редефинисала природу пословних односа, услова рада и осталих образаца живота радника широм света. COVID-19 је пандемија која утиче на велики број земаља на глобалном плану; постала је друштвени феномен и доминантна карактеристика која на више начина утиче на свет рада. Коронавирус је нова нормалност; то је ванредна ситуација коју дефинишу хаос, сложеност и ентропија и која онемогућава проактивно планирање, пре свега у контексту Зимбабвеа. Улагање у припремљеност за катастрофе има како друштвени, тако и пословни смисао (Maunganidze, Ncube \& Sibanda, 2013). Преко Министарства здравља и бриге о детету, влада Зимбабвеа је развила неколико стратегија и мера за спречавање ширења и последица коронавируса. Неке од мера уведених за индустрију подразумевају обавезно ношење маске, употребу средстава за дезинфекцију и мерење температуре за све запослене на радном месту. Остали послодавци увели су кампање за подизање свести, прихватне центре за раднике за које се сумња да су позитивни на вирус, као и смернице о хигијенским и превентивним мерама против ширења вируса COVID-19 на радном месту. Смишљене су политике безбедности и здравља на раду у вези са коронавирусом, а кодекс понашања се примењује да би се остварило поштовање прописа о вирусу COVID-19. Међутим, сви ови напори су бесмислени уколико не постоји међусобна сарадња радника у борби против COVID-19. Ово истраживање настоји да деконструише ставове запослених према мерама БЗР уведеним у оквиру рестрикција током пандемије COVID-19 у Зимбабвеу.

\section{2. Пандемија COVID-19}

Чињеница је да се природне катастрофе и несреће дешавају без обзира на то колико смо припремљени: оне се много чешће дешавају онда када их најмање очекујемо. Ncube (2014) помиње несрећу у окну Камандама у руднику угља Хванге из 1972. године, када је погинуло 427 рудара. Иста студија открила је да несрећа или катастрофа било ког обима има озбиљне последице по људе и наноси озбиљну штету животној средини и угрожава опстанак великог броја породица. Исти ставови односе се на циклон Идаи у марту 2019. године. Циклон је угрозио животе многих људи у Мозамбику и Зимбабвеу, нарочито у области Чиманимани. Много људи остало је без крова над главом, породице и пријатеља, а будућа радна снага нестала је због природне катастрофе током ноћи у петак 15. марта 2019. године. 
До данашњег дана се последице несреће у рудничком окну Камандама и циклона Идаи, између осталих, и даље осећају и утичу на друштвено-економски миље Зимбабвеа. Maunganidze, Ncube и Sibanda (2013) истражили су практичност проактивног планирања за случај катастрофа на радном месту. Утврдили су да без обзира на то колико су планови добро смишљени, несреће се ипак догађају. Утицај тих несрећа погоршава се због понашања и ставова људи према примени здравствених и безбедносних планова у ванредним ситуацијама и структура које их подржавају. Појединци не могу да верују да је COVID-19 реалност, али пружају отпор придржавању ограничења која су увели влада, СЗО, МОР и појединачне организације.

Коронавирус (COVID-19) је заразно респираторно обољење које изазива нови вирус познат као SARS-CoV-2. Обољење изазива респираторне сметње сличне грипу, са симптомима као што су висока температура, кашаљ и тешкоће у дисању. COVID-19 се појавио у Кини децембра 2019. године. Светска здравствена организација (C3O) објавила је епидемију вируса COVID-19 у јануару 2020. у кинеској провинцији Хубеи. Болест изазвана коронавирусом описана је као ванредна ситуација опасна по здравље на међународном нивоу. Према Међународној организацији рада (MOP), коронавирус се шири капљичним путем када неко ко има COVID-19 кашље или издахне ваздух, ослобађајући капљице заражених течности и те капљице падају на оближње предмете или површине. Човек се може заразити додиривањем контаминираних површина или предмета и затим додиривањем свог лица. COVID-19 се шири на исти начин као и грип. СЗО (2020) је изјавила да је 19. јула 2020. било 14,4 милиона потврђених случајева коронавируса, са 8,03 милиона излечених и 603.000 преминулих. Према извештају Министарства здравља и бриге о детету од 19. јула 2020, у Зимбабвеу је било 1.478 потврђених случајева, 439 излечених и 25 преминулих. Ове цифре показују нагли пораст у поређењу са 479 потврђених случајева, 63 излечена и 4 смртна случаја у Зимбабвеу на дан 19. јуна 2020. године.

\section{1. Изолација у Зимбабвеу}

COVID-19 је широм света оставио много људи без средстава за живот. Међународна организација рада (ILO, 2020) открива да су због коронавируса милиони радника остали без сигурности, прихода и хране, при чему је њихова будућност веома неизвесна. То је довело до пада од 60\% у приходима радника на глобалном плану, а када је реч о најосетљивијим групама на тржишту рада, 3,3 милијарде људи претрпело је огромну штету у погледу способности да зараде за живот услед кризе проузроковане пандемијом. Стога Uzhenyu (2020) потврђује да је COVID-19 утицао на све аспекте живота и на целокупну динамику индустријских односа у Зимбабвеу. Мере изолације су кључни разлог за забринутост који погоршава ситуацију прекарних радника конкретно у Зимбабвеу.

Влада Зимбабвеа увела је неколико мера у борби против ширења и последица вируса COVID-19. Као што наводи Uzhenyu (2020), Зимбабве је прво у понедељак, 30. марта 2020. године, увео националну изолацију у трајању од 21 дана, познату као изолација 4. нивоа. Сва предузећа су затворена осим оних са основним услугама, као што су радници обезбеђења, здравствени сектор, услужне станице, прехрамбени 
сектор и јавни превоз. Током ове фазе забрањена су окупљања више од 50 људи као начин примене социјалне дистанце, а позивало се на употребу средстава за дезинфекцију и одржавање личне хигијене. Затварање бројних организација значи да је већина радника остала код куће страхујући за своје здравље, безбедност и сигурност посла.

По истеку изолације 4. нивоа, влада је 3. маја 2020. објавила изолацију од додатних 14 дана са неколико ублажених ограничења (African Research Bulletin, 2020). Појединим организацијама, на пример онима у рударству, дозвољено је да раде током периода изолације 3. нивоа. Затим је објављена фаза изолације 2. нивоа, током које су поново отворена многа званично регистрована предузећа. Остала предузећа, попут комби превоза, забаве, школа, угоститељства и неформалног сектора и даље су остала затворена. Током овог периода радно време било је од 8.00 ујутру до 3.00 поподне, осим за оне у основним услугама, односно одобрене у смислу Статутарног инструмента 99 из 2020. године. Влада је објавила обавезне захтеве за спречавање вируса COVID-19, који обухватају, без ограничења, мерење телесне температуре, обавезно ношење маске и коришћење средстава за дезинфекцију површина и руку на свим радним местима. Уведене су мере безбедности и здравља на раду у циљу спречавања ширења и последица коронавируса. Дана 18. маја 2020. држава је објавила изолацију 2. нивоа до даљег, дајући појединим организацијама прилику да наставе пословање, али под условом да поштују и примењују ограничења у вези са COVID-19. Угоститељству је дозвољен рад, а радно време продужено је до 4.30 поподне.

COVID-19 изазвао је огромне невоље међу радницима у Зимбабвеу (Uzhenyu, 2020). Према MOP (ILO, 2020), радницима са несигурним запослењем су раскинути уговори, појединим запосленима су смањене плате, док остали нису добили чак ни део плате због слабог пословања и немогућности послодаваца да исплате зараде. Неке организације натерале су раднике да користе одмор током читавог периода изолације, а онима који нису имали довољно слободних дана саветовано је да узму неплаћено одсуство, док су појединци упућени да узму 12 дана специјалног одсуства који су им затим били одбијени од редовног годишњег одмора. Неки послодавци определили су се за смањење трошкова због природне катастрофе и немогућности да радницима исплате зараде током пандемије. Влада је увела Статутарни инструмент (SI) 99 и Статутарни инструмент 81 из 2020. године (Спецификација минималне зараде која је ступила на снагу 1. априла 2020). Према овом Инструменту, сваки послодавац треба да исплати минималну зараду од RTGS \$2.549,74 (зимбабвеански долар) или противвредност од $\$ 43.00$ (амерички долар), са изузетком пољопривредног сектора.

Обавештење 005/03/2020 Националног савета за запошљавање у пољопривредној индустрији у Зимбабвеу класификовало је пољопривредну индустрију као основну службу током периода изолације. Послодавци у овој индустрији позвани су да запосленима обезбеде личну заштитну опрему и одећу како би се спречио ризик од излагања вирусу COVID-19 на радном месту. Међутим, без обзира на напоре владе и компанија у спречавању вируса COVID-19 и његовог утицаја на економију и радна места, запослени на различите начине реагују на ограничења у вези са 
коронавирусом. Овај чланак покушао је да критички истражи понашање радника у односу на ограничења током пандемије COVID-19 на примеру пољопривредне индустрије у Зимбабвеу.

Ова студија даје одговор на следеће главно истраживачко питање:

Које обрасце понашања показују запослени у односу на мере БЗР током пандемије COVID-19?

Конкретни циљеви су:

a. установити утицај вируса COVID-19 на радне односе и услове рада,

b. описати обрасце понашања запослених у односу на ограничења уведена због коронавируса,

с. пронаћи стратегије које помажу у управљању неконвенционалном понашању запослених.

\section{3. Теоретски оквир}

3.1. Коеволуциона теорија и постмодернизам у вези са вирусом COVID-19

Организациони успех и учинак почивају на удруженим напорима, ставовима и понашању људског капитала. Снажна интеграција интерне стратегије компаније и њеног оперативног окружења, као и чврста повезаност структура, процеса, способности и управљања воде ка високом учинку (Maunganidze et al, 2013). Један од главних изазова који погађају компаније у пољопривредној индустрији, а нарочито у Зимбабвеу, јесте променљив пословни контекст, сложеност и неизвесност, поготово у случају природних катастрофа и ванредних ситуација. Ова студија је усвојила постмодернизам као смерницу, при чему је главни аргумент то да су пракса, планови и ограничења смишљени за управљање вирусом COVID-19 заправо производ сложених дискурзивних пракси припреме, закона дискурса и идеолошких утицаја (Fischer, 2003). Према ауторима Maunganidze et al (2013), улагање у припрему за катастрофе је разумно и оправдано у друштвеном и пословном смислу. Постмодернистички став указује на то да постоје вишеструке стварности које појединци граде; ако не постоји чврсто утврђена стварност, људи не могу да знају истину. Вишеструке стварности захтевају различите методе приступања пандемији COVID-19. Постмодернизам је блиско повезан са неуспехом шеме помоћи, система легитимитета, одлучности и сагласности у односу на коронавирус. Објашњавајући појаву и утицај вируса COVID-19 као нове нормалности, постмодернисти одбацују примену универзалних метода и макро-објашњења у корист нових стратегија за ограничавање проблематичних аспеката у искуствима Зимбабвеа. Коеволуциона теорија потврђује да се организације развијају у спрези са њиховим окружењем, а промене у сваком друштвено-економском контексту имају позитиван или негативан утицај на пословну одрживост и опстанак (Lewin \& Vilberda, 1999). Компаније А и Б изложене су коронавирусу који угрожава пословну ефикасност. Успех зависи од њихове способности да се боре, коеволуирају суочавајући се са вирусом COVID-19, да се позабаве изазовима појачаним током пандемије и да поново изграде позитивну културу међу запосленима. 


\section{4. Методологија}

Студија је усвојила квалитативни начин истраживања и заснована је на постмодернизму. Спроведена је користећи студије случаја две дрвне компаније, Компаније А и Компаније Б које послују у пољопривредном сектору Зимбабвеа. Обављена је анализа садржаја компанијских докумената као што су извештаји, политике и процедуре о здрављу и безбедности, медијски извештаји и тематске анализе. Коришћени су и примарни и секундарни подаци. Група од укупно 40 испитаника употребљена је за сакупљање података за ову студију; од њих су 5 били на руководећим позицијама, 4 из људских ресурса (HR), 10 су били представници радничких савета, 2 представници синдиката, а преосталих 19 били су запослени. Дискусије у фокусним групама служиле су за сакупљање података од радника и представника радничких савета, док су интервјуи у четири ока обављени ради сакупљања података од руководства, HR-a и чланова синдиката.

\section{5. Налази}

5.1. Утицај пандемије COVID-19 на односе у индустрији и услове рада

Студија је препознала неколико утицаја коронавируса на односе у индустрији и услове рада у оквиру пољопривредне индустрије Зимбабвеа. Испитаници из руководства истакли су да је затварање компанија и граница после објављивања изолације утицало на готовинске токове на извозном тржишту. То је смањило стварање прихода и способност организација да својим радницима исплате зараде. Један представник руководства Компаније А изјавио је следеће:

„Упадљив утицај пандемије COVID-19 у индустрији јесте то што се као компаније ослањамо на извозно тржиште у Боцвани, Мозамбику и Јужној Африци. Изолација је довела до затварања главних граничних прелаза, па је онемогућен превоз наших производа на инострано тржиште. То значи да смо у шкрипцу, да нам нису остављене никакве опције за стварање прихода, никакав приступ страним валутама, а немамо ни начина да набавимо резервне делове из иностранства. Тренутно послујемо испод 30\% због пандемије COVID-19, што није прихватљиво и, по мом мишљењу, нема пословног смисла."

Исто тако, испитаници из руководства Компаније Б потврдили су да су ограничења путовања и извоза услед мера изолације утицале на финансијску базу њихове компаније. Она не може да исплати зараде нити обезбеди повећање зараде радницима како би ублажила незабележену инфлацију и повећане трошкове живота. Чланови синдиката такође су открили да пандемија коронавируса негативно утиче на радничке накнаде јер бројни послодавци не успевају да исплате зараде због слабе продаје.

Запослени су изнели мишљење да су пољопривредне компаније класификоване као основне услуге, па послодавци треба да им редовно исплаћују довољну зараду током периода изолације. Један од представника радничког савета изјавио је:

„Класификовани смо као основна служба, па радимо током читавог периода изолације осим неколико појединаца који су отишли на одмор. Током овог периода 
наш послодавац није повећао плате нити нам је дао додатак за ризик с обзиром на то да је COVID-19 смртоносна болест. Мислили смо да ћемо добити додатак за рад у несигурним условима, као што је предвиђено Законом о раду, или да ће нам, послодавац платити прековремени рад у знак захвалности што радимо иако су нам безбедност и здравље угрожени."

Руководство обе компаније навело је да компаније немају могућност да повећају плате и дају додатке зато што је продаја на ниском нивоу; наравно, постоји масовна производња, али се сва роба налази у складиштима. Такође су изјавили да је пословање права уметност, процес производње и продаје, па кад производите, а не продајете, осуђени сте на пропаст.

Деветнаест испитаника из групе радника поновили су да су путовања ограничена због изолације и да се суочавају са потешкоћама када желе да оду из града и набаве основне намирнице. Исти испитаници такође су изјавили да је зарада коју добијају толико мала да не могу да плате аутобуску карту, при чему су се надали да ће током периода изолације добити прехрамбене пакете од послодаваца. На ту тему руководство је рекло да нема капацитете за обезбеђивање прехрамбених пакета због несташица хране и инфлације у локалним продавницама.

Чланови радничког савета изјавили су да су запослени из обе компаније морали да оду на одмор и неплаћено одсуство у случају да нису имали довољно слободних дана. Испитаници из руководства сматрају да је изолација била прилика да се запослени пошаљу на одмор и да се смање накнаде за одсуство. Међутим, један представник синдиката изјавио је:

„Видели смо како ови послодавци терају запослене да иду на одмор, а неки су морали на принудни одмор током периода изолације. Плате су смањене, што је имало озбиљан утицај на живот не само запослених, него и њихових породица и заједнице. Замислите да сте код куће без икаквог извора прихода; није разумно да добар послодавац пошаље раднике на принудни одмор. Изолација је само једна фаза, запослење је начин преживљавања за раднике, па сам мислио да би, у оквиру њихове стратегије задржавања запослених, компаније требало да исплате зараде, а не да шаљу на принудни одмор. Ово је природна катастрофа; ту смо да помажемо једни другима. То није предвиђено законом, али на основу добре праксе требало би радницима дати специјално одсуство, дати им плату док су код куће како би се подржале њихове друштвено-економске потребе."

Када је реч о уговорима о раду, представници HR-a и радничких савета поновили су да је COVID-19 погоршао несигурност посла за прекаријат. Ови испитаници су изјавили да већина радника у компанијама има уговоре на одређено време или о привременом раду. Због ограничења изазваних коронавирусом и изолацијом, њихови уговори о раду су раскинути и радници су добили отказ. Један синдикални функционер тврди да је COVID-19 погоршао положај лумпенпролетаријата односно прекарних радника; вирус је био катализатор њихових невоља и додатно је продужио неизвесност у погледу зараде и посла. Испитаници из руководства тврде да због изолације организацијама није остављена ниједна опција осим да раскину уговоре са радницима на одређено време. Ово је био оправдан покушај компанија да спрече високе трошкове радне снаге у односу на ниску производњу. 
Већина запослених, чланова синдиката, HR-a и радничких савета потврдила је да је COVID-19 донео мноштво изазова у вези са безбедношћу и здрављем на раду, као и низ утицаја у оквиру индустрије. Испитаници су тврдили да пре избијања пандемије COVID-19 компаније нису успеле да обезбеде довољно личне заштитне опреме, па су запослени радили без заштитне одеће, наочара, рукавица и обуће. Ово је био случај пре свега са прекарним радницима, а испитаници су открили да су ти радници изузетно осетљиви на ризик од вируса COVID-19. Избијање пандемије и захтеви у вези са безбедношћу донели су компанијама још један упадљив изазов. Ево шта је имао да каже један испитаник на руководећем положају:

„Због изолације не можемо да обезбедимо личну заштитну опрему из иностранства нити можемо да приуштимо да је набавимо у Зимбабвеу за више од 700 запослених јер је веома скупа. Када је реч о захтевима БЗР у вези са коронавирусом, и даље се мучимо, али смо успели да набавимо маске, уређаје за мерење температуре и средства за дезинфекцију на радном месту."

Испитаници из руководства такође су истакли да страх од коронавируса утиче на учинак запослених. Траума и страх од вируса COVID-19 стварају висок ниво несигурности у погледу посла међу запосленима, што уништава њихову мотивисаност, посвећеност и ангажовање. Запослени имају тенденцију да се понашају контрапродуктивно када су им безбедност и сигурност посла угрожени. а према изјавама руководства, COVID-19 је елемент ниске продуктивности радне снаге у пољопривредној индустрији.

Социјална и физичка дистанца је једно од ограничења у вези са вирусом COVID-19 које су истакли дословно сви испитаници (Табела 1). У оквиру дискусија у фокусним групама, представници радничких савета и запослени су се сагласили да је социјална и физичка дистанца мера у циљу спречавања ширења коронавируса на радном месту. Исти испитаници истакли су да социјална и физичка дистанца није лака због културолошких вредности и норми, као и због распореда њихових улога на радном месту. Један запослени је рекао следеће:

„Влада подстиче све да одржавају социјалну дистанцу, али није ми практично да одржавам социјалну и физичку дистанцу од својих колега на послу и од чланова породице. У фабрици размењујемо производе из једног центра са другим како бисмо направили финалне производе, реч је о производном ланцу. Понекад радимо чак и без заштитних рукавица, па је ризик од ширења вируса висок. Стога, жеља нас радника јесте да одбијемо рад под оваквим условима јер је наше здравље у озбиљној опасности, али видите, преживљавамо јер смо препуштени на милост и немилост послодаваца. Ово је разлог због којег се обично понашамо контрапродуктивно. Страх нас је да ћемо умрети."

Занимљиво је мишљење другог члана радничког савета:

„Не можемо бити присиљени на социјално и физичко дистанцирање, навикли смо на mushandirapamwe (зимбабвеанска филозофија која подразумева да сви раде као један). Мислим да је лаж рећи да COVID-19 постоји у Зимбабвеу; само ми покажите једну особу из окружења која је заражена или умрла од тог вируса." 


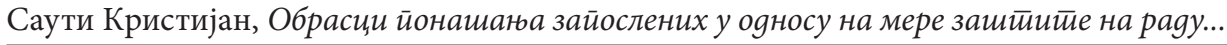

Испитаници из руководства указали су на то да је одржавање социјалне и физичке дистанце веома тешко с обзиром на природу послова. Један од представника руководства је изјавио:

„Понекад ови радници одбијају да одржавају социјалну и физичку дистанцу зато што им то није нормално. Они не верују да је коронавирус реалност. Они могу да се грле, деле храну и долазе у контакт на радном месту без икаквог страха од пандемије."

Поједини радници изразили су став да су маске обавезне, али да њихова суштина у спречавању коронавируса није реална. Руководство је указало да радници не носе маске тврдећи да због њих отежано дишу. Поједини радници сада користе маске како би се заштитили од прашине, а не да би спречили ширење вируса COVID-19. Испитаници из радничких савета и HR-a изразили су другачије мишљење од руководства, тврдећи да се радници заправо не плаше пандемије коронавируса. Један испитаник из HR-a изјавио је да радници нису продуктивни као што су били пре пандемије зато што се плаше и раде у паници.

Једно од ограничења у вези са вирусом COVID-19 јесте остајање код куће и избегавање непотребног путовања. Студија открива да радници у пољопривредној индустрији и даље одлазе на посао током пандемије, те да због строгих друштвено-економских захтева они не могу да приуште останак код куће. У оквиру дискусија у фокусним групама испитаници су изјавили да су ограничења, поготово она која се односе на путовања, имала сврху да спрече демонстрације, односно да нису била смишљена само да ублаже утицаје коронавируса већ да заштите политичке интересе. Један испитаник из радничког савета казао је:

„Речено нам је да останемо код куће, али је NEC утврдио да смо основна служба, па и даље идемо на посао јер су нам потребни храна и остале основне ствари. Није изводљиво остати код куће јер ћемо у противном умрети од сиромаштва. Викендом и када имамо слободне дане путујемо у Мозамбик да купимо јевтине намирнице, не можемо да издржимо без плате, па нас је глад принудила да одлазимо у Мозамбик по храну. Кад би нам влада обезбедила основне намирнице, били бисмо крајње захвални и могли бисмо да останемо код куће."

Када је реч о мерењу температуре, испитаници из руководства су изјавили да су компаније набавиле опрему за тестирање на свим улазним пунктовима. Међутим, запослени одбијају мерење температуре јер опрема увек даје нетачне резултате због хидрометеоролошких образаца у овим областима. Један запослени је изјавио:

„Не верујем тестовима јер је опрема неисправна. Мислим да је спољна температура у овим крајевима веома ниска. Ова област је веома хладна, па опрема за мерење некада покаже 0 степени Целзијусових. Нема потребе за таквим тестовима."

Поједини испитаници из HR-a и радничких савета, као и неки радници, изјавили су да употреба средстава за дезинфекцију руку није паметна идеја у пољопривредној индустрији. Они тврде да су јутра веома хладна и пошто је сада зима, радници одбијају да перу или дезинфикују руке. Овакав начин понашања изазива висок ризик од вируса COVID-19 у пољопривредној индустрији у Зимбабвеу. Представници 
руководства такође су рекли да радници краду средства за прање и дезинфекцију руку и користе их у друге сврхе уместо за спречавање коронавируса.

Сви радници, синдикални функционери и руководиоци поновили су да је свима забрањено додиривање лица у циљу спречавања ризика од коронавируса. Један од испитаника из руководства рекао је да се радници који се прљају док обављају посао зноје и немају избора већ морају да руком обришу зној са лица. Немогуће је избећи контакт са лицем (уста, очи и нос) у овој индустрији.

\section{2. Управљање понашањем запослених током пандемије COVID-19}

Испитаници из руководства изнели су занимљиво мишљење о управљању понашањем запослених током пандемије коронавируса. Ти испитаници поновили су да постоји потреба за усвајањем кампања за подизање свести и обуке запослених како би схватили проблеме везано за вирус COVID-19. Један испитаник је изјавио:

„Неки наши запослени не схватају да је COVID-19 реалност. Они желе да у то поверују тек када буду сведоци да се неко заразио на радном месту. Иако коронавирус односи животе, људи просто не верују, они су неверне Томе. Да би то схватили, неопходна је обука и покретање кампања за подизање свести. Ово ће помоћи да се промени култура отпора међу нашим запосленима како би могли да схвате да је коронавирус нова нормалност и да треба поштовати превентивне мере."

Синдикални функционери и чланови радничких савета изјавили су да компаније треба да обезбеде прехрамбене пакете и основне потрепштине запосленима како би се избегло њихово непотребно кретање и одлазак у Мозамбик. Осим тога, рекли су да држава такође треба да обезбеди бесплатну храну становништву како би се ублажила криза са храном која тренутно присиљава заједнице и запослене да крше мере заштите безбедности и здравља на раду чији је циљ да се спречи ширење и последице пандемије COVID-19.

Четири испитаника из руководства изнела су мишљење да запослене треба кажњавати због непридржавања ограничења у вези са вирусом COVID-19. Као што је наведено у члану 3.6 Кодекса понашања Компаније Б, кршење процедура и политика БЗР подразумева дисциплински поступак и правоснажну односно строгу казну. Један испитаник из руководства је изјавио:

„Треба кажњавати запослене који крше мере БЗР уведене у циљу спречавања вируса COVID-19. Држава преко полиције и војске кривично гони све који у јавности буду затечени без маске, па би то требало да важи и на радном месту, требало би кажњавати чак и оне који краду средства за дезинфекцију руку јер такво непримерено и девијантно понашање није прихватљиво."

Испитаници из HR-a истакли су да синдикати и раднички савети имају кључну улогу у стварању позитивног става према придржавању мера БЗР због вируса COVID-19 у пољопривредној индустрији. Испитаници су се сагласили да је улога форума представника радника да се баве разлозима за забринутост које људи имају у вези са БЗР, да те разлоге пренесу руководству и изграде међусобну сарадњу у оквиру индустрије за борбу против коронавируса. Један од испитаника из HR-a је рекао: 
„Синдикати попут Генералног синдиката радника у пољопривреди и земљорадњи Зимбабвеа (GAPWUZ) требало би да активно обучавају раднике да се придржавају нивоа ограничења против вируса COVID-19. Нажалост, никада нисмо видели да су бар један дан одвојили да се обрате радницима о начинима борбе против коронавируса на радном месту. Наши запослени верују синдикатима, па их љубазно молимо да дођу и интервенишу у борби против пандемије COVID-19. Таква међусобна сарадња је најбољи пут ка пословном и друштвеном интегритету."

\section{6. Дискусија}

\section{1. Утицај пандемије COVID-19 на односе у индустрији и услове рада}

Ова студија утврдила је да коронавирус има неколико утицаја на радне односе и услове рада у пољопривредној индустрији у Зимбабвеу. Коронавирус утиче на одрживост пословања услед затварања граница и извозног тржишта. То је ослабило способност организација да исплате накнаде и повећају наднице радницима током периода изолације. Ово је у складу са мишљењем аутора Ncube (2020) који тврди да је COVID-19 променио дефиницију природе радних односа у Зимбабвеу. Послодавци нису у могућности да користе инострано тржиште и да стварају високе приходе. То је донело изазове за раднике на више различитих начина. Поједини послодавци не могу да исплате наднице и плате, док други шаљу запослене на принудни одмор (Uzhenyu, 2020). Ово је јасан доказ да је COVID-19 променио природу индустријских односа и услова рада у Зимбабвеу.

Истраживање је открило да је коронавирус повећао број раскинутих уговора са радницима на одређено време. То прати висок ниво пословне несигурности за раднике са прекарним запослењем у пољопривредној индустрији Зимбабвеа. Исте ставове подржава Uzhenyu (2020) који тврди да су због вируса COVID-19 бројни послодавци раскинули уговоре са радницима на одређено и са хонорарним запослењем. То значи да је прави благослов имати сигуран посао у ери коронавируса; раднике са несигурним запослењем мучи неизвесност да ли ће остати без посла, што утиче на њихове породице и живот уопште. Запослени за стално такође страхују због посла и препуштени су на милост и немилост послодавцима који могу да смање радну снагу из оправданих разлога изазваних ванредном ситуацијом.

Налази откривају да COVID-19 утиче на индустријске односе и на морал запослених на радном месту. Запослени раде без личне заштитне опреме, па су због тога изложени ризику од коронавируса. Оваква ситуација могла би да утиче на психолошки уговор и да наведе раднике на контрапродуктивно понашање, односно на то да реагују тако што ће покушати да обнове своју личну безбедност. То је у складу са оним што тврде Bhebhe (2020) и Lang (2020), тj. да је COVID-19 катализатор отпора радника и криминогених радњи, што доводи до контрапродуктивног понашања као што су саботажа и лоше пружање услуга. Коронавирус негативно утиче на однос између послодаваца и запослених. Препреке указују на то да руководиоци не подржавају нити воде рачуна о људским ресурсима јер им не обезбеђују довољно заштитне одеће како би се спречило ширење вируса COVID-19. 


\section{2. Деконструисање понашања запослених у погледу ограничења током пандемије COVID-19}

Налази откривају различите ставове које запослени заузимају према мерама Б3Р чији је циљ успоравање ширења вируса COVID-19 на радном месту. Већина испитаника потврдила је да су друштвено-културне вредности врло снажне и да је социјална/физичка дистанца начин за уништавање друштвених веза на радном месту и у друштву. Међународна организација рада (MOP) (ILO, 2020) и Ozili (2020) износе став да се ограничења уведена за спречавање коронавируса крше у већини афричких друштава и радних места због културолошких и друштвених убеђења. Запослени у пољопривредној индустрији пружају отпор социјалном и физичком дистанцирању због тога што не схватају да је COVID-19 реалност.

Страх од губитка посла је главни разлог за забринутост због којег радници и даље раде иако немају заштитну одећу како би избегли ризик од вируса COVID-19. Као што ова студија открива, радници су препуштени вољи послодаваца. То указује да су запослени изложени несигурним условима рада, да добијају казне и произвољне отказе, па самим тим доживљавају висок ниво пословне несигурности. Ово је у складу са моделом запослења који су представили Lewchuk, de Wolff и King (2003), а према којем нестабилни услови рада и неизвесност стварају осећање страха, забринутости, фрустрираности и синдром преживелих, који су сви контрапродуктивне природе. То значи да када послодавци прибегну непотребним раскидима уговора о раду, неправедним отказима или смањењу радне снаге током пандемије коронавируса, преостали запослени изложени су великим емоцијама, стресу и несигурности у вези са послом. Они који задрже посао самим тим ће прибећи разним облицима непримерених радњи као што су ситне крађе, саботажа и варање како би на свом радном месту обновили слободу у контексту израбљивачког капиталистичког рада.

Студија открива да радници због тога редовно одлазе на посао, али да раде без довољно личне заштитне опреме како би задржали посао и добијали ниске наднице. Њихов образац рада не дозвољава социјалну дистанцу, те отуд отпор према придржавању мера БЗР против коронавируса. Ово је у складу са ставовима МОР (ILO, 2020); Светске здравствене организације (C3O) (WHO, 2020); African Research Bulletin (2020) и аутора Keune и Pedaci (2019), који тврде да већина прекарних радника има ограничена права на радном месту, па су стога најосетљивији на утицај пандемије COVID-19. Ови радници изложени су експлоатацији и разним облицима непримерених услова рада. Запослени који раде у небезбедним условима могу да усвоје стратегије преживљавања као што су крађа хемикалија или алатки предвиђених за заштиту од вируса COVID-19. То је начин за обнављање њихове слободе и контролисање ситуације на радном месту у оквиру пандемије коронавируса.

Резултати студије указују на то да запослени носе маске како би се заштитили од прашине, а не спречили ширење вируса COVID-19, те да верују да ограничења у вези ca COVID-19, на пример ограничена путовања, имају за циљ да одрже политичке интересе избегавањем демонстрација у Зимбабвеу. Овај став односи се на демонстрације планиране за 31. јул 2020. године, које су организоване због тврдњи о злоупотреби људских права и због кризе без преседана у Зимбабвеу. Chirimambowa (2020) подржава став радника у пољопривредној индустрији тврдећи да је у Зимбабвеу 
пандемија дала савршену прилику за заустављање непрестаних приговора опозиције и цивилног покрета, те да су рестрикције у вези са COVID-19 смишљене да остваре неометан империјалистички ауторитаријанизам. Влада Зимбабвеа обуставила је демонстрације како би избегла брзо ширење пандемије коронавируса, али радници у пољопривредном сектору сматрају да је то био начин да се спрече демонстрације чији је циљ био остваривање права радника на социјалну правду и демократију. Министарство здравља и бриге о детету изјављује да запослени показују тенденцију отпора према употреби маски, али да су маске веома важне у спречавању ширења вируса COVID-19. Маске онемогућавају пренос капљица и не служе само за заштиту од прашине на радном месту. Неопходно је обучити запослене како би схватили да се коронавирус може ширити капљичним путем, па је због тога употреба маски оправдан начин за смањивање ризика (United Nations, 2020).

Студија показује контрадикцију између два мишљења - руководства и запослених - у вези са поимањем вируса COVID-19 и понашањем запослених. Руководство верује да се запослени не плаше пандемије, па чак деле храну и грле се, што је против мера Б3Р у циљу спречавања вируса COVID-19, односно одржавања социјалне и физичке дистанце. С друге стране, радници и $\mathrm{HR}$ приписују ниску продуктивност страху радника од смртоносне пандемије. Maunganidze (2014) и Ncube (2020) тврде да је руководство увек имало на уму сопствене интересе, не уважавајући на прави начин потребе пролетаријата у погледу БЗР. Радници су одсечени од друштва и прави су пример сиромаштва, па је дељење хране уобичајено и тешко је поверовати у то да им је мотив непоштовање мера БЗР без претходног уважавања њихових друштвено-економских потреба. Уколико послодавци не покажу никакву вољу да подрже раднике и осигурају заштитну одећу и осталу опрему за заштиту од вируса COVID-19, радници ће очигледно одбити да се придржавају мера и почеће да показују девијантно понашање.

\section{3. Управљање понашањем запослених током пандемије COVID-19}

Налази су открили да би организације требало да усвоје кампање за подизање свести и да обучавају запослене како да схвате проблеме везано за вирус COVID-19. Као превентивна мера, запослене би требало подучавати да би у потпуности схватили утицаје и начине управљања коронавирусом. Uzhenyu (2020); MOP (ILO, 2020) и C3O (WHO, 2020) деле исти аргумент. Они тврде да организације треба да обучавају своје особље о хигијени и осталим превентивним мерама како би се избегао ризик од вируса COVID-19. Обуке и кампање за подизање свести изградиће нову културу међу радницима који ће прихватити да је коронавирус нова нормалност (Wilder-Smith \& Freedman, 2020). То ће створити међусобну повезаност и усаглашеност између запослених и њиховог предузећа са животном средином. Организације треба да обучавају запослене како би они могли да постигну посвећеност и дубоку мотивисаност током пандемије коронавируса. То би повећало способност организација да коеволуирају, да се изборе са пандемијом и усвоје стратегије преживљавања како би постигле успех.

Синдикати и раднички савети треба да имају значајну улогу у образовању и комуникацији са радницима о природи и утицајима вируса COVID-19 на радном 
месту. Ncube (2020) тврди да су синдикати и даље од пресудног значаја упркос променама и катастрофама које се дешавају на глобалном плану. Делотворна комуникација на радном месту може се постићи преко синдиката и радничких савета зато што су то важне институције у очима запослених који желе да изразе своје разлоге за забринутост и незадовољство. Синдикати би такође требало да преговарају са руководством о обезбеђивању личне заштитне опреме како би се сачували људски животи.

Студија је открила да руководство верује у неопходност покретања дисциплинских поступака против запослених који крше мере БЗР уведене због вируса COVID-19. Кодекси о понашању запослених примењују се за дисциплиновање запослених који крше превентивне мере у вези са вирусом COVID-19, што јасно сведочи о несигурном положају радника у пољопривредној индустрији. Ово је у складу са ставом aутора Maunganidze (2014) који доводи у питање оперативну природу кодекса о понашању запослених. Исти аутор тврди да је примена Кодекса о понашању саставни део плана који служи за легитимизацију власти, контроле и експлоатације од стране руководства над обичним радницима. Примена ових кодекса у случају кршења прописа о пандемији COVID-19 није неопходна, нарочито када послодавци нису у стању да обезбеде довољно заштитне опреме и избегну изложеност радника коронавирусу. Запослени су крајње несигурни због уништавања и угрожавања радне средине; они раде без довољно заштитне одеће док истовремено добијају мизерне наднице испод линије апсолутног сиромаштва. Дисциплински укори и откази због непридржавања мера БЗР уведених због пандемије нису рационални из перспективе Фукоових концепата зато што су сведени било на казнене законике или правилнике, те се самим тим не баве хуманитарним питањима радника током пандемије COVID-19.

\section{7. Закључци и препоруке}

Установљено је да је COVID-19 реалност; то је нова нормалност. Од огромног значаја је низ ограничења или мера у циљу ублажавања ширења вируса. Овај чланак утврдио је да коронавирус има озбиљан утицај на услове рада и радне односе. Радници су изложени небезбедном радном окружењу, добијају ниске наднице, а неки су чак и дисциплински кажњени због непоштовања безбедносних прописа. Када је реч о прекарним радницима и њиховим уговорима, они опстају тако што су препуштени на милост и немилост послодаваца и суочени са високим нивоом пословне несигурности. Ова питања озбиљно утичу на ангажованост, морал и мотивисаност запослених; она утичу на функционисање психолошког уговора јер код запослених изазивају трауму и страхове. Студија открива да запослени оспоравају ограничења попут обавезног мерења телесне температуре, ношења маски и социјалног дистанцирања јер их виде као начин за уништавање друштвених веза и културе, као и начин на који се штите туђи политички интереси. Ово је довело до распрострањеног отпора према придржавању мера БЗР уведених у пољопривредној индустрији током пандемије COVID-19. Негативне перцепције запослених и њихов недостатак разумевања за важност ограничења значе да постоји потреба за стратешком интервенцијом у оквиру примене и функционисања мера за управљање пандемијом COVID-19 у зимбабвеанској економији. 
Истраживање наводи да су неопходни обука, делотворна комуникација преко радничких савета и синдиката, кампање за подизање свести, посвећеност руководства да радницима обезбеди довољно личне заштитне опреме, као и усклађивање са хидрометеоролошким обрасцима како би се добила подршка особља. Борба против коронавируса треба да буде удружена, а понашање засновано на подршци и интегрисаности да би се задовољиле потребе како појединаца, тако и организација. COVID-19 је друштвени феномен; он је „рак-рана” која уништава друштвено-економску ефикасност широм света. Као што тврде Lone и Ahmad (2020), запослене треба подстаћи да поштују мере Б3Р уведене због вируса COVID-19 и да га прихвате као нову реалност која дефинише свет рада у 21. веку. Не препоручује се примена кодекса о понашању запослених јер они погоршавају нестабилан положај радника и представљају израбљивачку природу руководства, а не баве се правом суштином. Примена ових кодекса може изазвати отпор и сукобе, те отуд потреба за применом других мера као што су обука и делотворна комуникација за приступање опасности од коронавируса.

Неопходно је заштитити раднике од нестабилних услова рада који су додатно погоршани пандемијом COVID-19 како широм света, тако и у Зимбабвеу. COVID-19 је постао нова нормалност; променио је дефиницију природе света рада. Појединим радницима је смањена зарада; онима са привременим запослењем су раскинути уговори, док су они чији су уговори истекли неправедно отпуштени. Послодавци треба да поштују основна права радника, нарочито она која истичу Универзална декларација УН о људским правима и МОР. У Зимбабвеу послодавци треба да штите интересе и права радника предвиђена Законом о раду (поглавље 28:01), Уставом из 2013. и Кодексом о запошљавању (Статутарно запошљавање 15 из 2006). Поштовање одредаба Закона о раду унапредиће пристојан рад и промовисати хармоничне индустријске односе, што заједно води ка врхунском учинку и конкурентној предности.

Капацитет државе и организација у вези са здравственом заштитом и БЗР има пресудну улогу у управљању и контроли вируса COVID-19. Lone и Ahmad (2020) наводе да Велика Британија, Сједињене Америчке Државе и Кина имају напредне системе здравствене заштите, али се такође муче да би спречиле коронавирус. За земље у развоју као што је Зимбабве, који има слабији здравствени сектор, неопходно је да из садашње кризе извуку поуке о припремљености за природне катастрофе у будућности. Иако је у многим афричким земљама уведен низ стратешких мера као што су изолација, забрана путовања, забрана великих скупова и обавезно ношење маске да би се контролисало ширење вируса COVID-19, владе и даље треба да унапређују своје здравствене установе, а корпорације такође треба да се усредсреде на људске ресурсе на радном месту да би показале своје разумевање суштине тих мера против вируса COVID-19.

Ова студија заснована је на обрасцима понашања запослених према мерама БЗР против вируса COVID-19 у пољопривредној индустрији у Зимбабвеу. Препоручује се даље истраживање коришћењем вишеструких студија случаја из разних индустрија како би се сачинила упоредна анализа понашања, ставова и перцепција запослених у вези са ограничењима уведеним због вируса COVID-19. 


\section{REFERENCES / ЛИTЕРАTУРA}

African Research Bulletin (2020). Zimbabwe: Coronavirus Lockdown. SA: John Wiley \& Sons Ltd.

Bhebhe, M. (2020). Employee disengagement from the perspective of frontline employees; A Hotel case study in Zimbabwe. Journal of Management and Administration, $1(1), 73-100$.

Brehm, J. W. (1966). A theory of psychological reactance. New York: Academic Press.

Brehm, S. S. and Brehm, J. W. (1981). Psychological Reactance. A theory of freedom and control. New York: Academic Press.

Chirimambowa, T.C. (2020). COVID-19 and the Future of Democracy in Zimbabwe. The Elephant. https://www.theelephant.info/features/2020/07/11/covid-19-and-the-future-of-democracy-in-zimbabwe/? Retrieved on August 19, 2020.

Fischer, F. (2003). Reframing Public Policy. Oxford University Press.

ILO (2020). ILO Standards and COVID-19 (Coronavirus) FAQ, Key provisions of international labour standards relevant to the evolving COVID-19 outbreak https://www.ilo. org/wcmsp5/groups/public/ed_norm/ormes/documents/publication/wcms_739937 pdf. Retrieved on July 10, 2020.

ILO, (2020). In the face of a pandemic: Ensuring Safety and Health at Work, https://www. ilo.org/wcmsp5/groups/public/ed_protect/protrav/fework/documents/publication, wcms_742463.pdf. Retrieved on July 08, 2020.

Keune, M., and Pedaci, M. (2019). Trade union strategies against precarious work: Common trends and sectoral divergence in the European Union. European Journal of Industrial Relations, 1-17.

Laing, T. (2020). The economic impact of the Coronavirus 2019 (Covid-2019): Implications for the mining industry. Elsevier Public Health Emergency Collection, 7(2), 580-582.

Lewchuk, W., de Wolff, A. and King, A. (2003). From job strain to employment strain: Health effects of precarious employment. Just Labour, 3, 23-25.

Lone, S. A. and Ahmad, A. (2020) COVID-19 - an African perspective. Emerging Microbes \& Infections, 9(1), 1300-1308.

Maunganidze, L., Ncube, F. and Sibanda, P. (20130 Rethinking Pro-Active Disaster Planning in the Workplace: The Case of a selected Mine in Zimbabwe. International Journal of Business and Management, 8(15), 90-98.

Ministry of Health and Child Care (2020). COVID-19 Update.: Highlights of the situation report. Retrieved from http://www.mohcc.gov.zw/index.php?option=com on July 20, 2020.

Ncube, F. (2014). Down the memory lane: Revisiting the 1972 Hwange Colliery Kamandama Disaster. International Journal of Art \& Humanity Science, 1(XX), 55-65.

Ncube, F. (2020). Developments and Changes Adversely Affecting Trade Unions in the Hospitality Industry of Zimbabwe. African Journal of Hospitality, Tourism and Leisure, 9(3), 199-214.

Ozili, P. K. (2020). COVID-19 in Africa: Socioeconomic Impact, Policy Response and Opportunities. International Journal of Sociology and Social Policy, Retrieved from https://www.researchgate.net/publication/340610720 on July 16, 2020. 
Sibanda, P., Mavenga, E., Maunganidze, L. and Ncube, F. (2014). Employees' reactance and survival strategies in an underperforming Zimbabwean parastatal. African Journal of Business Management, 8(22), 1043-1052.

United Nations 92020) Policy Brief: Impact of COVID-19 in Africa. United Nations Economic Commission of Africa. Retrieved from https://www.uneca.org/publications Retrieved on July 16, 2020.

Uzhenyu, D. (2020). Employment relations dynamics in the midst of COVID-19 induced national lockdown. The Zimbabwean scenario. Human Capital Development, 2, 4-7.

WHO (2020). Coronavirus disease 2019 (COVID-19) Situation Report - 94. Retrieved from https://www.who.int/publications-detail/infection-prevention on July 15, 2020.

WHO (2020). Operational considerations for COVID-19 management in the accommodation sector. Available at: https://apps.who.int/iris/bitstream/handle/10665/331937/WHO2019-nCoV-Hotels-2020.2-eng.pdf

Wilder-Smith, A., and Freedman, D. O. (2020). Isolation, quarantine, and social distancing and community containment: pivotal role for old-style public health measures in the novel Coronavirus (2019-nCoV) outbreak. Journal of Travel Medicine, 27(2). 


\section{ПРИЛОГ / AРPЕNDIX}

Table 1: Employee behaviours towards Restrictions for COVID-19 Disease / Табела 1: Понашаюе зайослених у односу на оіраничень увеgена збоі вируса COVID-19

\begin{tabular}{|c|c|}
\hline \begin{tabular}{|l|}
$\begin{array}{l}\text { Number/ } \\
\text { Број }\end{array}$ \\
\end{tabular} & Description of Restriction/Ойuс оїраничења \\
\hline 1. & Social and physical distancing/Социјална и физичка дистанца \\
\hline 2. & Face Masks/Macke \\
\hline 3. & $\begin{array}{l}\text { Staying at home and avoiding unnecessary movement/Остајање код куће и } \\
\text { избегавање непотребног кретања }\end{array}$ \\
\hline 4. & $\begin{array}{l}\text { Compulsory body temperature screening/Обавезно мерење телесне } \\
\text { температуре }\end{array}$ \\
\hline 5. & Hand sanitizing and use of disinfectants/Средства за прање и дезинфекцију руку \\
\hline 6. & $\begin{array}{l}\text { Avoiding contact with face (eyes, nose and mouth)/Избегавање контакта са } \\
\text { лицем (очи, нос и уста) }\end{array}$ \\
\hline
\end{tabular}

